\title{
Article \\ Morphological Abnormalities and Gene Expression Changes Caused by High Incubation Temperatures in Zebrafish Xenografts with Human Cancer Cells
}

\author{
Pablo Cabezas-Sainz ${ }^{1}$, Carlos Coppel ${ }^{1}$, Alba Pensado-López ${ }^{1,2}{ }^{\oplus}$, Pedro Fernandez ${ }^{1}$, \\ Laura Muinelo-Romay ${ }^{3,4}{ }^{\oplus}$, Rafael López-López ${ }^{5}$, Juan A. Rubiolo ${ }^{1, *}$ and Laura Sánchez ${ }^{1,6, *(D)}$ \\ 1 Department of Zoology, Genetics and Physical Anthropology, Universidade de Santiago de Compostela, \\ Campus de Lugo, 27002 Lugo, Spain; pablo.cabezas@usc.es (P.C.-S.); carloscoppel13@gmail.com (C.C.); \\ alba.pensado.lopez@rai.usc.es (A.P.-L.); pedro.fernandez.garcia@rai.usc.es (P.F.) \\ 2 Genomic Medicine Group, Center for Research in Molecular Medicine and Chronic Diseases (CiMUS), \\ Universidade de Santiago de Compostela, 15782 Santiago de Compostela, Spain \\ 3 Liquid Biopsy Analysis Unit, Oncomet, Health Research Institute of Santiago de Compostela (IDIS), \\ 15706 Santiago de Compostela, Spain; lmuirom@gmail.com \\ 4 Centro de Investigación Biomédica en Red de Cáncer (CIBERONC), 29029 Madrid, Spain \\ 5 Translational Laboratory, Medical Oncology Department, Complexo Hospitalario Universitario de Santiago \\ de Compostela/SERGAS, 15706 Santiago de Compostela, Spain; rafael.lopez.lopez@sergas.es \\ 6 Preclinical Animal Models Group, Health Research Institute of Santiago de Compostela (IDIS), \\ 15706 Santiago de Compostela, Spain \\ * Correspondence: jarubiolo@usc.es (J.A.R.); lauraelena.sanchez@usc.es (L.S.); Tel.: +34-982-822-429 (L.S.)
}

Citation: Cabezas-Sainz, P.; Coppel, C.; Pensado-López, A.; Fernandez, P.; Muinelo-Romay, L.; López-López, R.; Rubiolo, J.A.; Sánchez, L.

Morphological Abnormalities and Gene Expression Changes Caused by High Incubation Temperatures in Zebrafish Xenografts with Human Cancer Cells. Genes 2021, 12, 113. https://doi.org/10.3390/ genes12010113

Received: 26 November 2020 Accepted: 13 January 2021 Published: 19 January 2021

Publisher's Note: MDPI stays neutral with regard to jurisdictional clai$\mathrm{ms}$ in published maps and institutional affiliations.

Copyright: (C) 2021 by the authors. Licensee MDPI, Basel, Switzerland. This article is an open access article distributed under the terms and conditions of the Creative Commons Attribution (CC BY) license (https:// creativecommons.org/licenses/by/ $4.0 /)$.

\begin{abstract}
Published studies show that most of the human cancer xenograft studies in zebrafish embryos have used incubation temperatures in the range of $32-34{ }^{\circ} \mathrm{C}$ for $3-6$ days post-injection, trying to find a compromise temperature between the zebrafish embryos $\left(28^{\circ} \mathrm{C}\right)$ and the human injected cells $\left(37^{\circ} \mathrm{C}\right)$. While this experimental setup is widely used, a question remains: is possible to overcome the drawbacks caused by a suboptimal temperature for the injected cells? To clarify the effect of temperature and injected cells on the host, in this study, we analyzed the development and health of the last in response to different temperatures in the presence or absence of injected human cancer cells. Comparing different incubation temperatures $\left(28,34\right.$ and $\left.36^{\circ} \mathrm{C}\right)$, we determined morphological abnormalities and developmental effects in injected and non-injected embryos at different time points. Besides this, the expression of selected genes was determined by qPCR to determine temperature affected metabolic processes in the embryos. The results indicate that an incubation temperature of $36^{\circ} \mathrm{C}$ during a period of $48 \mathrm{~h}$ is suitable for xenotransplantation without morphological or metabolic changes that could be affecting the host or the injected cells, allowing them to proliferate near their optimal temperature.
\end{abstract}

Keywords: zebrafish; development; xenotransplantation; incubation-temperature; gene-expression

\section{Introduction}

Zebrafish embryos have been widely used as a model for cancer research since 2006 [1] by means of the xenograft technique. The procedure involves the injection of human cancer cells in different parts of zebrafish embryos, being the yolk and circulation injections at $48 \mathrm{~h}$ post-fertilization (hpf) the most widely used [2,3]. Additionally, xenograft studies can also be carried out in other sites of the embryos by cancer cell injection in the common cardinal vein, the brain, the perivitelline space, or the pericardial cavity at $48 \mathrm{hpf}, 4$ days post fertilization (dpf), or even in the adult fish $[4,5]$. The principal aim of this type of study is the determination of the injected cells' fate and the effect of selected known/new compounds or chemotherapeutic drugs onto them [6]. Although many aspects of the technique had been studied in the last decade (site of injection, number of injected cells, image analysis, 
etc.) to develop and describe a model for the study of human cancer and its therapy [7], the incubation temperature of the embryos have not received much attention. Most of the studies have focused on the proliferation/invasion of cancer cells without the assessment of the incubation temperature effect on the host and the cell-host interaction underlying this process. While zebrafish embryos have an optimal developmental temperature of $28^{\circ} \mathrm{C}$ [8], in xenograft experiments, a compromise temperature between host optimal growth temperature and that ideal for the human injected cells $\left(37^{\circ} \mathrm{C}\right)$ is used [9]. This temperature should be high enough for xenografted cells to grow properly, while allowing the embryos to stay alive and without malformations that compromise their survival during the experiment. The selected temperature for a given experiment will also differentially affect host gene expression. Previous works showed that a high incubation temperatureaffected genes involved in stress response, immune response and development [10].

In xenograft, experiments temperature is important for the proliferation and migration of the injected cells. Considering this and the restrictions imposed by the host tolerance to temperature, a range of incubation temperatures $\left(31^{\circ} \mathrm{C}\right.$ to $\left.36^{\circ} \mathrm{C}\right)$ have been assayed in xenografted zebrafish embryos to study injected cancer cells behavior, metabolic phenotype, or invasion capacity [11-14]. Results from in vitro studies on tumor cell proliferation, migration, and invasion at different temperatures $\left(31-37^{\circ} \mathrm{C}\right)$ suggest that temperatures closer to $37^{\circ} \mathrm{C}$ are necessary to obtain reliable results when studying this type of cellular process [15].

The problem with xenograft studies in zebrafish at temperatures close to $37{ }^{\circ} \mathrm{C}$ is that, as described in other fish species [16], heat-induced teratogenic effects are expected. Teratogenic effects could be quite different at the temperature range of use in xenograft studies $\left(31-37^{\circ} \mathrm{C}\right)$ and should be determined to better understand the interactions, if any, between the host and the tumor cells. For this purpose, based on previous reports on temperature effects during zebrafish embryo development [17], we analyzed the teratogenic effects quantifying specific embryo malformations at different time points. While $34{ }^{\circ} \mathrm{C}$ or lower is the selected temperature in most of the zebrafish xenograft studies informed so far in the literature, we showed that these are feasible at $36{ }^{\circ} \mathrm{C}$, reducing incubation time [7]. At $36^{\circ} \mathrm{C}$, we observed a higher injected cell proliferation rate when compared to lower temperatures, without significant host mortality. In this work, we focused on the quantification of malformations due to the differential temperature-induced teratogenic effects and determined their relation with embryo mortality to better characterize the zebrafish xenograft model at $36^{\circ} \mathrm{C}$.

Apart from embryo malformations, in xenograft experiments, temperature affects the expression of genes involved in several metabolic pathways involved in immune/stress response, inflammation, and development interfering with the overall state of the host $[10,18]$. While lacking an adaptive immune system, zebrafish embryos have an innate immune system at the time of tumor cell injection (48 hpf) $[19,20]$. Because of this, a differential immune and stress response at different temperatures could be interfering with the embryo reaction to the human injected cells. We analyzed this assaying the effect of temperature on selected genes.

\section{Materials and Methods}

\subsection{Zebrafish Handling}

One-year-old adult zebrafish (Danio rerio, wild-type, strain $\mathrm{AB}$ ) were maintained at $28{ }^{\circ} \mathrm{C}$ in $30 \mathrm{~L}$ aquaria at a rate of 1 fish per liter of water, with a light-dark cycle of 14:10 hours. The aquarium is located in the veterinary facility of the University of Santiago de Compostela (Lugo, REGA code ES270280346401). Zebrafish embryos were obtained by mating adults according to previously described procedures [8]. Zebrafish care, use and treatment were performed in agreement with the European Parliament and Council Directive 2010/63/EU on the protection of animals used for scientific purposes and the Spain Royal Decree 53/2013 on animal welfare standards. Experimental protocols were approved by the Ethical Committee of the University of Santiago de Compostela 
$(15,010 / 2015 / 001)$. After the experimental procedures, zebrafish embryos were euthanized with a tricaine (Sigma) overdose.

\subsection{Cell Culture and GFP Labeling}

The MCF7 human breast cancer cell line was obtained from the American Type Culture Collection (ATCC) and cultured using RPMI medium (GIBCO, Invitrogen-Carlsbad, CA, USA) containing $10 \%$ FBS (GIBCO, Invitrogen) and $1 \%$ Pen/Strep (GIBCO, Invitrogen), at $37{ }^{\circ} \mathrm{C}$ with $5 \% \mathrm{CO}_{2}$ in a humidified atmosphere. For constitutive GFP labeling, cells were transduced using a lentiviral-driven GFP construct (Mission TurboGFP, SHC003V, Sigma-San Luis, Misouri, USA) following the manufacturer's instructions. GFP-positive cells were selected $72 \mathrm{~h}$ post-infection, adding $10 \mu \mathrm{g} / \mathrm{mL}$ puromycin to the culture media.

\subsection{Cancer Cell Injection in Zebrafish Embryos}

Embryos were collected and grown at $28^{\circ} \mathrm{C}$ in Petri dishes at a ratio of 50 embryos/plate. Two days post fertilization (dpf), embryos were dechorionized (if needed) and anesthetized with $0.003 \%$ tricaine (Sigma). GFP-labeled MCF7 breast cancer cells $(10,000-20,000$ cells $/ \mu \mathrm{L})$ were loaded into borosilicate glass capillary needles (1 mm O.D. $\times 0.75 \mathrm{~mm}$ I.D.; World Precision Instruments-Hitchin, Hertfordshire, UK) and injected at an average of 150-250 cells/embryo into the yolk sac using IM-31 electric microinjector (Narishige). We discarded embryos showing cells outside the yolk.

\subsection{Incubation and Assays Conditions}

Embryo incubation was performed at $28{ }^{\circ} \mathrm{C}, 34^{\circ} \mathrm{C}$ and /or $36{ }^{\circ} \mathrm{C}$ in $140 \mathrm{~mm} \times 20 \mathrm{~mm}$ Petri dishes (DeltaLab) at the ratio of 50 embryos/plate, using a minimum of two plates per replica, and preventing the plates from touching the metal parts of the incubator to avoid water overheating. Every $24 \mathrm{~h}$, the egg water (salt dechlorinate tap water, SDTW) was renewed to account for evaporation, oxygen reduction or accumulation of excretion substances from the embryos. Embryos incubated for more than $6 \mathrm{dpf}$ were feed twice per day with Gemma 75 (Skretting). Each assay described below was performed in triplicate.

\subsubsection{Assay Starting at $0 \mathrm{hpf}$}

Embryos were collected at $0 \mathrm{hpf}$ and screened after $1 \mathrm{hpf}$ to guarantee a normal cell division, eggs showing abnormal or asymmetric cell division were discarded and replaced by normal ones in order to reach the selected number of embryos for each treatment. Embryos were placed before $2 \mathrm{hpf}$ in Petri dishes at two different temperatures $\left(28^{\circ} \mathrm{C}\right.$ and $36^{\circ} \mathrm{C}$ ) and incubated for $48 \mathrm{hpf}$ screening the embryos for different malformations and mortality at previously determined critical developmental time points $(5 \mathrm{~h}, 10 \mathrm{~h}, 24 \mathrm{~h}$, $48 \mathrm{~h}$ ) [15]. After incubation, the hatching rate was quantified, and the embryos were placed at $28{ }^{\circ} \mathrm{C}$ to assay the mortality at different time points up to $336 \mathrm{hpf}$ (14 dpf) (Figure 1).

\subsubsection{Assay Starting at $48 \mathrm{hpf}$}

Zebrafish embryos were incubated at $28^{\circ} \mathrm{C}$ until $48 \mathrm{hpf}$. Afterward, embryos showing a normal developmental pattern were divided into three groups: (1) non-injected controls, (2) Injected with vehicle (RPMI) and (3) Injected with MCF7 breast cancer cell line. Embryos were then incubated for $48 \mathrm{~h}$ at $28^{\circ} \mathrm{C}, 34^{\circ} \mathrm{C}$, and $36^{\circ} \mathrm{C}$ until $4 \mathrm{dpf}$. After differential temperature incubation, embryos were returned at $28^{\circ} \mathrm{C}$ and were further incubated up to $14 \mathrm{dpf}$. Embryos were screened for mortality on a daily basis, and morphological abnormalities were screened at $0,2,6$, and 12 days post-injection (dpi) (Figure 1).

\subsection{Embryo Imaging}

Embryos were screened using an AZ-100 (Nikon) fluorescence stereomicroscope to identify and quantify relevant abnormalities: spinal deviation, edema, hatching rate, and head deformation (including ear malformations, abnormal eye size and mouth) for all the 
treatments described in the previous section. Malformations are expressed as percentages of the total embryos alive at the time point analyzed.

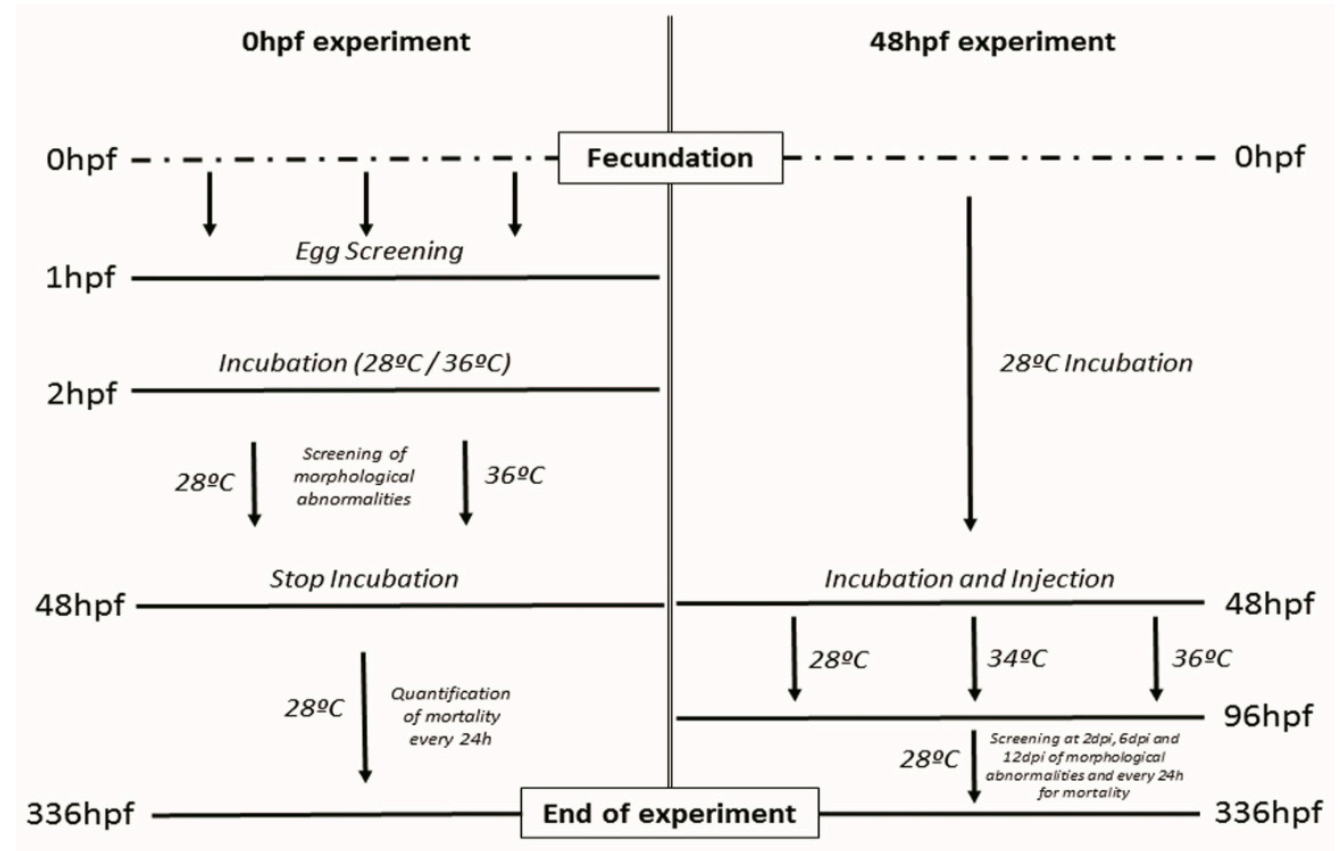

Figure 1. Overview of the two assays starting at two different start points. Hpf $=$ hours post-fertilization. Dpi $=$ days post-injection.

\subsection{RNA Isolation, $c D N A$ Synthesis and $q P C R$}

To determine the differential effect of temperature on gene expression at $34^{\circ} \mathrm{C}$ and $36{ }^{\circ} \mathrm{C}$, we selected genes previously shown to be affected by the temperature at $34{ }^{\circ} \mathrm{C}$ [10]. We also analyzed the expression of the following genes relevant for metabolic pathways that could be interfering with the normal proliferation and behavior of the xenograftedcells as a consequence of the cell-host interaction: development (lft2, mmp9, haus3, junb- $a$ and lum), immune response (socs $3 a, j u n b-a, \operatorname{tnfa}, \operatorname{csf} 3 a, \operatorname{csf} 3 b$ and il1b), stress response (apex1, hspa9), and metabolism (per2, wisp) (Table S1). For gene expression quantification, conditions from the previous experiment were replicated, dividing the embryos into three different groups based on incubation temperature $\left(28{ }^{\circ} \mathrm{C}, 34{ }^{\circ} \mathrm{C}\right.$ and $\left.36{ }^{\circ} \mathrm{C}\right)$ starting at $48 \mathrm{hpf}$ and up to $96 \mathrm{hpf}$. After differential temperature incubation, embryos were returned to $28^{\circ} \mathrm{C}$ to recover for another $72 \mathrm{~h}$ (from $96 \mathrm{hpf}$ to $168 \mathrm{hpf}$ ). A total of 10 embryos were euthanized and disaggregated in triplicate for each incubation temperature $\left(28^{\circ} \mathrm{C}, 34^{\circ} \mathrm{C}\right.$ and $36{ }^{\circ} \mathrm{C}$ ) after $96 \mathrm{hpf}$ (differential temperature effect) and after $168 \mathrm{hpf}$ (recovery effect). We used the RNeasy mini kit (QIAGEN, Hilden, Germany) to extract embryo RNA from the cell suspension after disaggregation of each condition following the manufacturer's instructions. After DNAse treatment, cDNA was synthesized using the AffinityScript multi-temperature cDNA synthesis kit (Agilent Technologies, Santa Clara, CA, USA), following the manufacturer's instructions. Gene expression was assayed using the Brilliant III Ultra-Fast SYBR ${ }^{\circledR}$ Green QPCR Master Mix (Agilent Technologies-Santa Clara, CA, USA) in a Stratagene Mx3005P quantitative PCR. Relative fold changes of gene expression normalized to $\beta$-actin as the housekeeping gene were calculated using the $\Delta \Delta \mathrm{Ct}$ method.

\subsection{Statistical Analysis}

GraphPad Prism version 7.00 for Windows (GraphPad Software, La Jolla, CA, USA) was used for statistical analysis. Unpaired Student's t-test was performed to analyze the mortality and morphological defects from $0 \mathrm{hpf}$ to $48 \mathrm{hpf}$; differences were considered significant when $p<0.05$. One-way ANOVA was used to analyze the morphological 
abnormalities experiment beginning at $48 \mathrm{~h}$ and the qPCR experiments. Differences were considered significant when $p<0.05$.

\section{Results}

\subsection{Mortality and Morphological Effects Comparison between $28^{\circ} \mathrm{C}$ and $36^{\circ} \mathrm{C}$ from $0 \mathrm{hpf}$ to $48 \mathrm{hpf}$}

We explored the possibility of exposing the embryos from nearly $0 \mathrm{hpf}$ up to $48 \mathrm{hpf}$ to a high incubation temperature $\left(36^{\circ} \mathrm{C}\right)$ and determine if this acclimation before the injection could interfere in the development and mortality of the embryos in the long-term.

Zebrafish embryos were harvested at $0 \mathrm{hpf}$, incubated at $28^{\circ} \mathrm{C}$ and $36^{\circ} \mathrm{C}$ for $48 \mathrm{~h}$. Embryos incubated at $36^{\circ} \mathrm{C}$ were returned to $28^{\circ} \mathrm{C}$, and incubation continued until $336 \mathrm{hpf}$ (14 dpf). Different morphological abnormalities were observed at $36{ }^{\circ} \mathrm{C}$, not evident at $28^{\circ} \mathrm{C}$. These included spinal deviation, probably due to a higher developmental speed at $36^{\circ} \mathrm{C}$, edema, and head deformation. Besides these, the hatching rate of the embryos was increased drastically at $36^{\circ} \mathrm{C}$ (Figure S1). No statistical difference in mortality was observed for the embryos incubated up to $48 \mathrm{hpf}$ at $28^{\circ} \mathrm{C}$ compared to embryos incubated at $36^{\circ} \mathrm{C}$. Although the mortality of the embryos stabilizes from $24 \mathrm{hpf}$ onwards, in the first $24 \mathrm{~h}$ of development, the mortality at $36^{\circ} \mathrm{C}$ occurs earlier than at $28^{\circ} \mathrm{C}$ (Figure S2B). To test if the incubation at $36^{\circ} \mathrm{C}$ from $0 \mathrm{hpf}$ to $48 \mathrm{hpf}$ produce long term effects, the embryos were incubated at $28^{\circ} \mathrm{C}$ for the rest of the experiment until $336 \mathrm{hpf}(14 \mathrm{dpf})$, checking the mortality on a daily basis. Results show that there were no differences and, therefore, no long-term effects from the incubation at $36{ }^{\circ} \mathrm{C}$ in the first $48 \mathrm{hpf}$ (Figure S2A).

\subsection{Mortality and Morphological Analysis at Different Incubation Temperatures in $48 \mathrm{hpf}$ Embryos}

\subsubsection{Mortality}

Forty-eight hpf embryos were incubated at $28^{\circ} \mathrm{C}, 34^{\circ} \mathrm{C}$, and $36^{\circ} \mathrm{C}$ for $48 \mathrm{~h}$. Mortality assessment showed a mild increase in mortality at $34{ }^{\circ} \mathrm{C}$ and $36{ }^{\circ} \mathrm{C}$ when compared to embryos incubated at $28^{\circ} \mathrm{C}$ (Figure 2A). No differences were observed between injected embryos at $34{ }^{\circ} \mathrm{C}$ and $36^{\circ} \mathrm{C}$. These results imply that xenotransplantation assays are possible using $48 \mathrm{hpf}$ embryos, at $36^{\circ} \mathrm{C}$ for $48 \mathrm{~h}$, without higher mortality in comparison to incubation at $34{ }^{\circ} \mathrm{C}$.

A

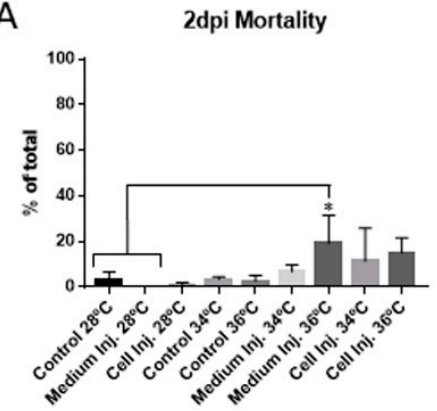

B

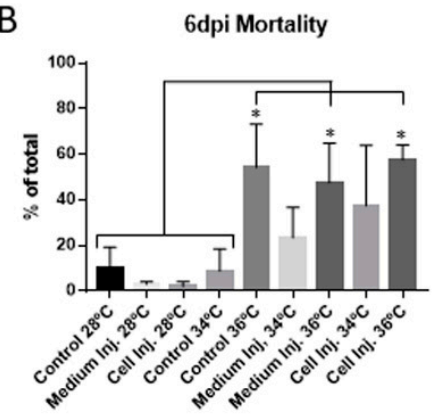

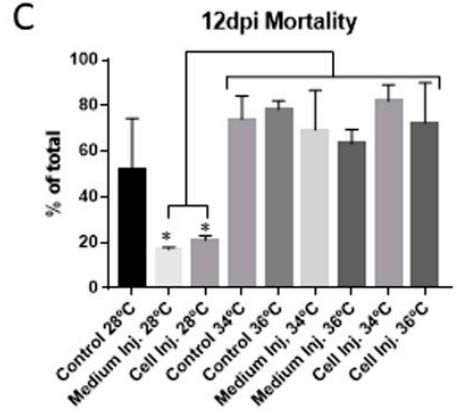

Figure 2. Mortality quantification at different time points comparing the different incubation conditions of the zebrafish embryos. (A) Mortality quantified at 2 dpi. (B) Mortality quantified at 6 dpi. (C) Mortality quantified at 12 dpi. Parameters are expressed as percentages from the total number of embryos assayed for each condition, comparing the incubation of the embryos from $2 \mathrm{dpi}$ to $12 \mathrm{dpi}$ at $28^{\circ} \mathrm{C}, 34^{\circ} \mathrm{C}$ and $36^{\circ} \mathrm{C}$. Error bars represent the standard deviation (SD). One-way ANOVA was performed, and differences were considered significant when ${ }^{*} p<0.05\left(\mathrm{n}_{28}{ }^{\circ} \mathrm{C}=150, \mathrm{n}_{34}{ }^{\circ} \mathrm{C}=150, \mathrm{n}_{36}{ }^{\circ} \mathrm{C}=120\right)$. The experiment has been performed in triplicate.

Embryos incubated at $34{ }^{\circ} \mathrm{C}$ and $36{ }^{\circ} \mathrm{C}$ for $48 \mathrm{~h}$ were then returned to $28{ }^{\circ} \mathrm{C}$, and incubation was carried on up to $6 \mathrm{dpi}$. At this time, the mortality was significantly different between control, medium injected, and cell injected embryos at $36^{\circ} \mathrm{C}$ compared to all the conditions at $28{ }^{\circ} \mathrm{C}$ and the controls incubated at $34^{\circ} \mathrm{C}$ (Figure 2B). While no significant increase in mortality was observed at $34^{\circ} \mathrm{C}$, a clear tendency of higher mortality was 
observed that was later confirmed, after another six days of recovery at $28^{\circ} \mathrm{C}$. The mortality of the embryos incubated at $34{ }^{\circ} \mathrm{C}$ and $36{ }^{\circ} \mathrm{C}$ increased to around $80 \%$, with significant differences between all the conditions assayed at these temperatures compared to those at $28^{\circ} \mathrm{C}$. The exception was $28^{\circ} \mathrm{C}$ incubated controls due to the high variability obtained in this condition (Figure 2C). At this time point, at least $20 \%$ of the mortality can be explained by the undergoing metamorphosis process between $12 \mathrm{dpf}$ and $14 \mathrm{dpf}$. Added to this is the mortality attributed to the high incubation temperatures and/or injection suffered during the experiment.

\subsubsection{Morphological Abnormalities}

Representative morphological defects (Figure S1) were quantified and analyzed for the same experimental conditions described in the previous section, including xenografted embryos, even if the cells suffer from cell death during the process of returning the embryos to a normal temperature of $28^{\circ} \mathrm{C}$ (Figure S3).

No clear differences in morphological abnormalities were observed after $2 \mathrm{dpi}, 6 \mathrm{dpi}$ or $12 \mathrm{dpi}$ at $28^{\circ} \mathrm{C}, 34^{\circ} \mathrm{C}$, and $36^{\circ} \mathrm{C}$ except for the case edema for which a significant increase was observed in xenografted embryos incubated at $36^{\circ} \mathrm{C}$ after $6 \mathrm{dpi}$ (Figure 3). Therefore, related to xenograft assays, there are no statistical differences between cell injection at $34^{\circ} \mathrm{C}$ and $36{ }^{\circ} \mathrm{C}$ in terms of morphological abnormalities of the embryos at $2 \mathrm{dpi}$. Even without statistical significance, spinal deviation and edema at $2 \mathrm{dpi}$ is present in conditions related to the incubation at $36^{\circ} \mathrm{C}$ (Figure $3 \mathrm{~A}, \mathrm{~B}$ ) and could be considered a teratogenic effect of the temperature $\left(36^{\circ} \mathrm{C}\right)$ at the final point of the xenograft experiment, but not interfering in mortality (Figure 2) or the correct proliferation of the injected cells, as described in previous studies [7].

\subsubsection{Gene Expression Related Changes}

In order to address the metabolic pathways affected in embryos exposed to $34^{\circ} \mathrm{C}$ and $36^{\circ} \mathrm{C}$, we measured gene expression changes of selected genes at different time points:

Gene expression after $48 \mathrm{~h}$ at $28^{\circ} \mathrm{C}, 34^{\circ} \mathrm{C}$, and $36^{\circ} \mathrm{C}$.

The expression of lft2, lum, csf3a and csf $3 b$ showed no significant differences between the temperatures assayed. On the contrary, socs $3 a, \operatorname{mmp} 9$, apex1, hspa9, junba, wisp, haus3, per2, tnfa and $i l 1 b$ were up or downregulated at $34{ }^{\circ} \mathrm{C}$ and $36{ }^{\circ} \mathrm{C}$ compared to the controls at $28{ }^{\circ} \mathrm{C}$ (Figure $4 \mathrm{~A}$ ).

Differences in gene expression between $34{ }^{\circ} \mathrm{C}$ and $36{ }^{\circ} \mathrm{C}$ were observed for $m m p 9$, junba and haus3. These genes are related to the developmental processes of the embryos, suggesting an altered development between the two incubation temperatures (Figure 4A) and also between these temperatures and that optimal for growth.

\subsubsection{Gene Expression after $72 \mathrm{~h}$ of Recovery at $28^{\circ} \mathrm{C}$}

After the recovery for $72 \mathrm{~h}$ following the incubation at $34{ }^{\circ} \mathrm{C}$ and $36{ }^{\circ} \mathrm{C}$ for $48 \mathrm{~h}$, some differences persist in the gene expression of the genes analyzed. The expression of $\operatorname{socs} 3 a$, haus3, il1b, csf3a and csf3b were up or downregulated compared to the control at $28{ }^{\circ} \mathrm{C}$ (Figure 4B). Differences in gene expression in embryos incubated at $34^{\circ} \mathrm{C}$ and $36{ }^{\circ} \mathrm{C}$ were also observed for $\operatorname{socs} 3 a$ and $\operatorname{csf} 33$, both of them related to the immune response (Figure $4 \mathrm{~B}$ ). In the case of socs $3 a$, an inverse response was observed for both conditions when compared to controls, while $c s f 3 b$ increased for embryos incubated at $36^{\circ} \mathrm{C}$ after recovery at $28^{\circ} \mathrm{C}$ with no such response observed for embryos incubated at $34^{\circ} \mathrm{C}$. 
A 2dpl Spinal Deviation

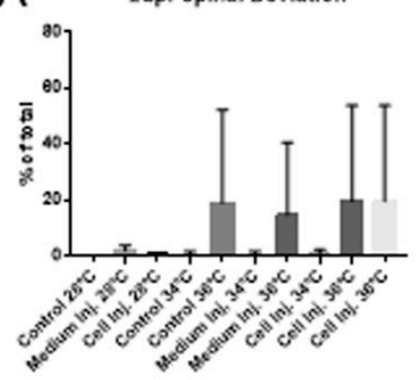

B

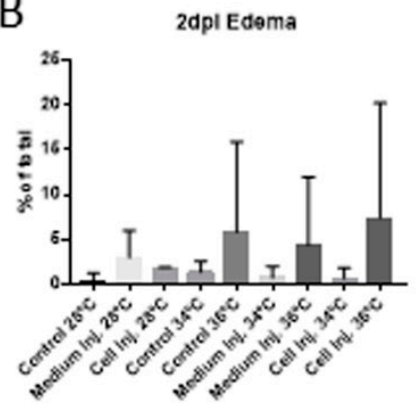

C

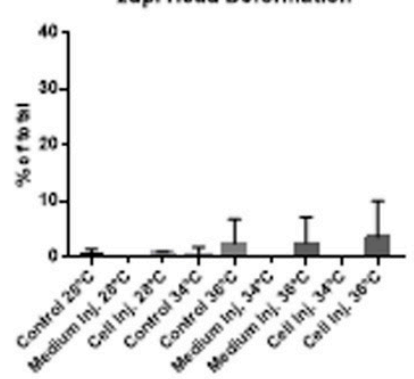

6dpl Spinal Deviation

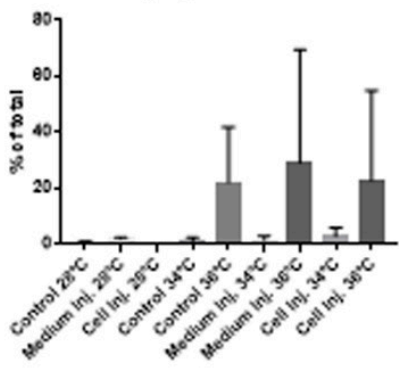

6dpI Edema

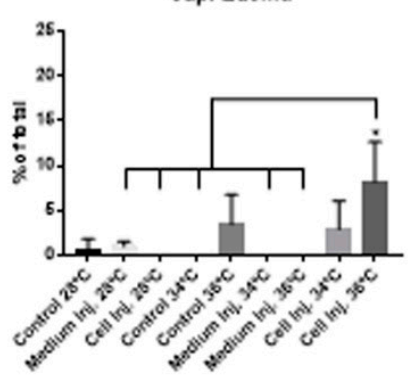

Gdpl Head Deformation

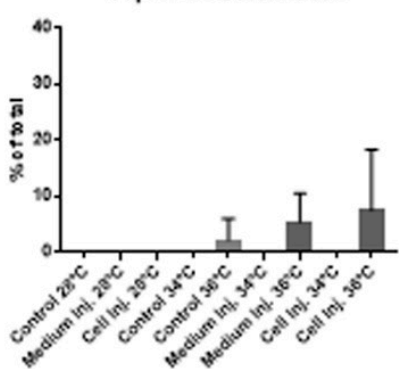

12dpl spinal Deviation

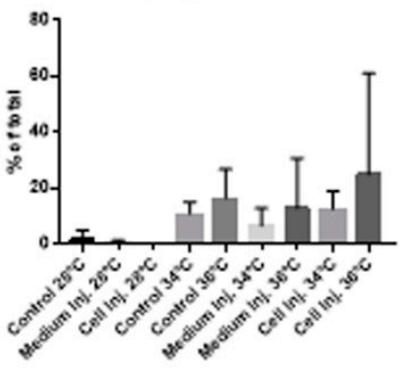

12dpl Edema

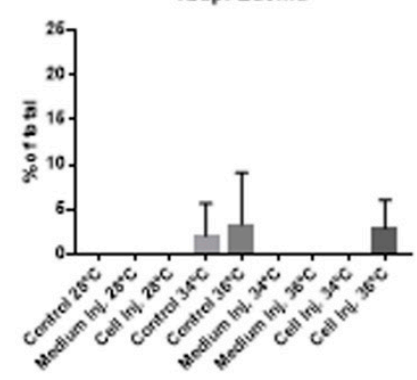

Figure 3. Morphological abnormalities quantification comparing the different times and incubation temperatures assayed. (A) Spinal deviation. (B) Edema. (C) Head deformation. In all cases, values are expressed as the percentage of the total number of embryos assayed for each condition comparing the incubation of the embryos for $48 \mathrm{~h}$ at $28^{\circ} \mathrm{C}, 34{ }^{\circ} \mathrm{C}$ and $36^{\circ} \mathrm{C}$ and the posterior recovery at $28^{\circ} \mathrm{C}$ until the end of the experiment. Error bars represent the standard deviation (SD). One-way ANOVA was performed, and differences were considered significant when ${ }^{*} p<0.05\left(\mathrm{n}_{28^{\circ} \mathrm{C}}=150, \mathrm{n}_{34^{\circ} \mathrm{C}}=150\right.$, $\left.\mathrm{n}_{36^{\circ} \mathrm{C}}=120\right)$. The experiment was performed in triplicate. 


\section{A $\quad 48 \mathrm{~h}$ of incubation}
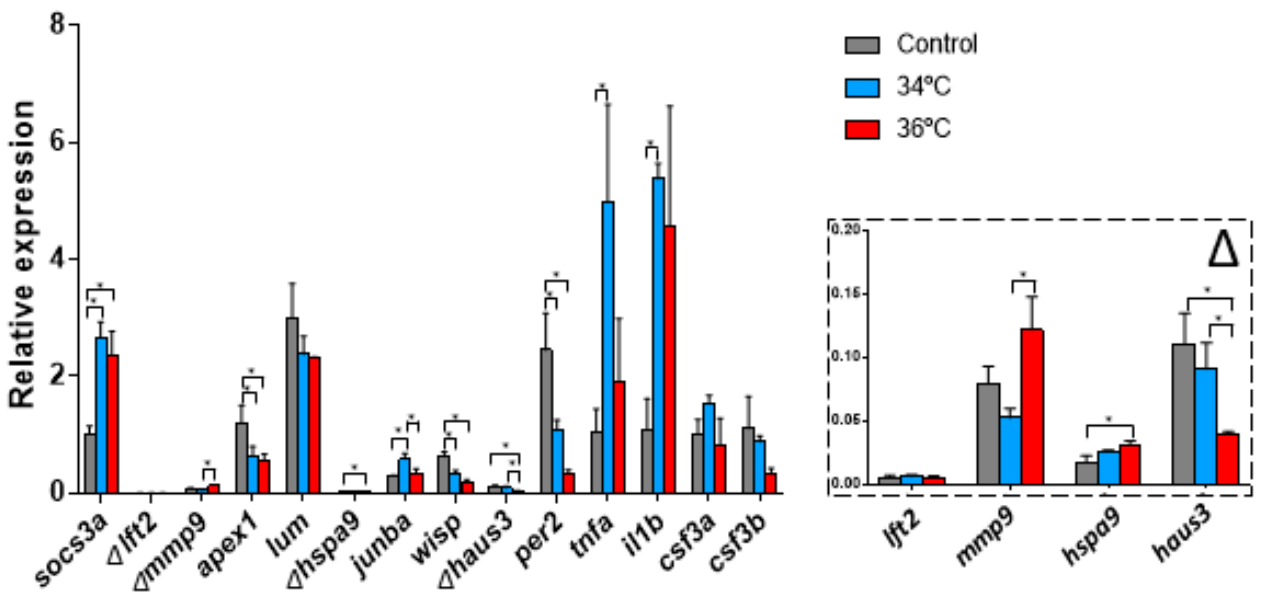

B

$72 \mathrm{~h}$ of recovery
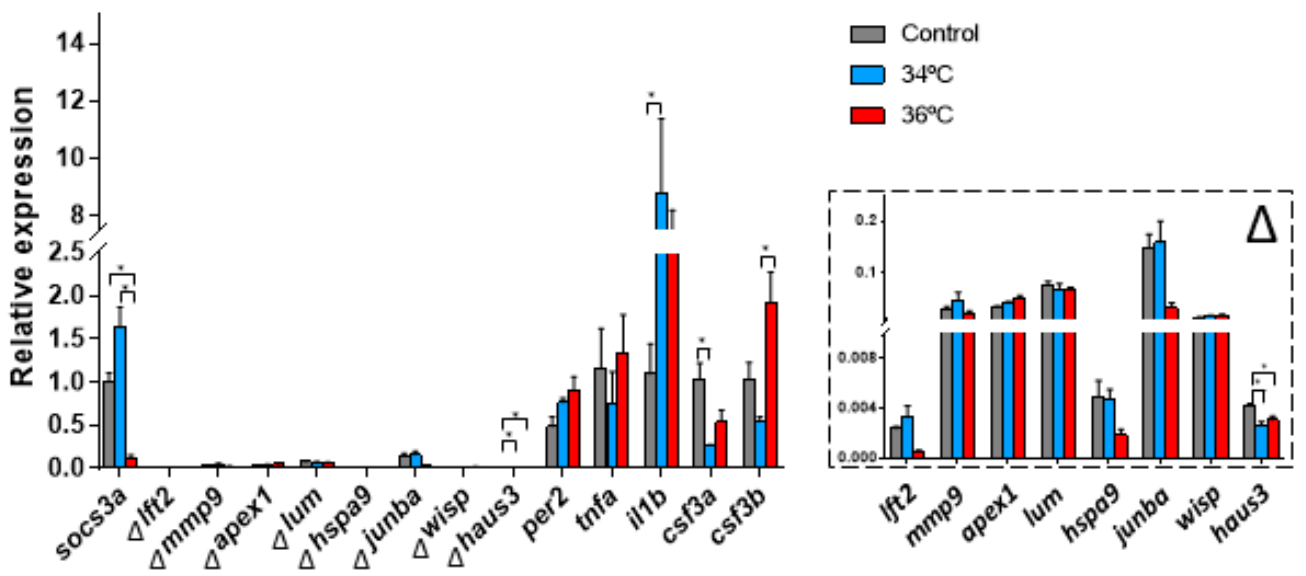

Figure 4. Embryo gene expression analyzed by qPCR after incubation at $28{ }^{\circ} \mathrm{C}, 34{ }^{\circ} \mathrm{C}$, and $36{ }^{\circ} \mathrm{C}$ for $48 \mathrm{~h}(\mathrm{~A})$ and for $48 \mathrm{~h}$ plus $72 \mathrm{~h}$ recovery at $28^{\circ} \mathrm{C}(\mathbf{B}) . \mathrm{N}=10$ embryos/temperature and time point in triplicate. One-way ANOVA was performed, and differences were considered significant when ${ }^{*} p<0.05 . \Delta=$ in the detailed view of marked genes.

\section{Discussion}

Zebrafish has gained relevance for being an excellent animal model to study human cancer [21,22]. It is a low-cost, fast and accurate model for high-throughput screening of drugs or new compounds due to their mass offspring and the possibility of performing xenotransplantation assays $[23,24]$. This last has greatly evolved during the last decade with several standard protocols already established. Despite this, several drawbacks still remain [15], among which host integrity-due to the high incubation temperature needed for xenografted cells to grow properly-is key to obtain accurate results for tumor cell response to applied treatments. This is highlighted in a recent work in which the effect of 5-Fluorouracil in zebrafish xenografted colorectal cancer cells was assayed. Different inhibition ratios were obtained depending on the incubation temperature of the embryos, showing a stronger decrease in cancer cells when the incubation temperature was $36^{\circ} \mathrm{C}$ compared to $34{ }^{\circ} \mathrm{C}$ [7].

We have previously shown that incubating embryos at $36{ }^{\circ} \mathrm{C}$ for up to three days is feasible, and no higher mortality is observed when compared to embryos incubated a $34{ }^{\circ} \mathrm{C}$ [7]. At the same time, it was recently reported that incubation of zebrafish embryos at $32.5^{\circ} \mathrm{C}$ and above causes malformations [17]; other authors reported normal development up to $35.5^{\circ} \mathrm{C}[25,26]$. In this work, we aimed to finely study the effect of the temperature 
range used in xenograft experiments on the host and further explore the possibility of increasing the temperature of xenograft assays up to $36^{\circ} \mathrm{C}$.

In the first experiment, embryos were incubated at $36^{\circ} \mathrm{C}$ from $0 \mathrm{hpf}$ to $48 \mathrm{hpf}$ to confirm if they could be more sensitive in this stage of development to temperature. While mortality was not different at $48 \mathrm{hpf}$ when compared to previous reports [17], significant spinal deviation and edemas were present in most of the embryos incubated at $36^{\circ} \mathrm{C}$. Apart from that, at $48 \mathrm{hpf}$, the hatching rate of the embryos was higher at $36^{\circ} \mathrm{C}$ due to the increase in development speed possibly produced by temperature. Interestingly, the hatching rate of $36.5^{\circ} \mathrm{C}$ is $0 \%$ [17], pointing to an inflexion point in the tolerated temperature between 36 ${ }^{\circ} \mathrm{C}$ and $36.5^{\circ} \mathrm{C}$. When fish were returned to an optimal temperature, after incubation at $34{ }^{\circ} \mathrm{C}$ and $36^{\circ} \mathrm{C}$, and incubated up to $14 \mathrm{dpi}$, no differences in mortality were observed between treatments at $28^{\circ} \mathrm{C}, 34^{\circ} \mathrm{C}$, and $36^{\circ} \mathrm{C}$ (Figure S2B). The zebrafish developmental stage most sensitive to temperature appears to be between $5 \mathrm{hpf}$ and $24 \mathrm{hpf}$ (Figure S2A).

In a second experiment, we incubated xenografted and control embryos for 2 days at $34{ }^{\circ} \mathrm{C}$ (the most used temperature for this type of experiment [27-29]) and $36{ }^{\circ} \mathrm{C}$ to compare temperature-induced mortality, morphological defects, and metabolism. In terms of mortality, the first stage of development from $0 \mathrm{hpf}$ to $48 \mathrm{hpf}$ (previous experiment) produced different results than those observed for the incubation at $36^{\circ} \mathrm{C}$ from $48 \mathrm{hpf}$ to $96 \mathrm{hpf}$, with the posterior recovery of the embryos from $96 \mathrm{hpf}$ to $336 \mathrm{hpf}$. The different conditions assayed (control, injected with RPMI medium or injected with MCF7 cells) at this stage of development showed that the embryos are less sensitive to the higher temperature than in the first $48 \mathrm{~h}$ of development. The temperature has a higher impact on development between $0 \mathrm{hpf}$ and $48 \mathrm{hpf}$, yielding more abnormalities and mortality of the embryos. The lack of differences in mortality and malformations in injected embryos between $34{ }^{\circ} \mathrm{C}$ and $36{ }^{\circ} \mathrm{C}$ after $2 \mathrm{dpi}$, from $48 \mathrm{hpf}$ to $96 \mathrm{hpf}$, allow xenograft assays to be performed at $36^{\circ} \mathrm{C}$ to determine xenografted cells proliferation, invasion or drug effects. To reach an incubation temperature ideal for tumor cells, without increased mortality or defects in embryos, a reduction in incubation time from 6 days to 2 days is required. Even this, more consistent and realistic results with regard to tumor cell proliferation could be expected. On the contrary, xenograft experiments at lower temperatures, with an increased incubation time, could lead to lower tumor cell proliferation and, consequently, an overestimation of the chemotherapeutic effect for assayed drugs [7].

We also analyzed the expression of genes related to development, immune system, stress, and metabolism to assess the effect of the incubation temperatures assayed over important metabolic pathways that could be influencing xenograft assays on zebrafish embryos according to previous works [10].

After $48 \mathrm{~h}$ of embryo incubation at $34^{\circ} \mathrm{C}$ and $36{ }^{\circ} \mathrm{C}$ compared to the control at $28^{\circ} \mathrm{C}$, some differences in the gene expression were found. When compared to embryos incubated at $28{ }^{\circ} \mathrm{C}$, the expression of socs $3 a, h s p a 9$, junba, tnfa and $i l 1 b$ were upregulated, and the expression of apex1, wisp, haus3 and per 2 were downregulated in embryos incubated at $34{ }^{\circ} \mathrm{C}$ and $36{ }^{\circ} \mathrm{C}$. The most relevant differences observed in the present study are the ones that arose from the comparison of $34{ }^{\circ} \mathrm{C}$ against $36{ }^{\circ} \mathrm{C}$ (Figure $4 \mathrm{~A}$ ). Comparing results obtained at $28{ }^{\circ} \mathrm{C}$ with those obtained at $34^{\circ} \mathrm{C}$ and $36^{\circ} \mathrm{C}$, per2, a gene which downregulation enhances the expression of proinflammatory cytokines [30], was one of the most downregulated genes due to the temperature increase. On the contrary, socs $3 a$, involved in immune response and inflammatory pathways, tissue regeneration and in the repression of the STAT3 signaling pathway, was upregulated. The STAT3 pathway is involved in the regeneration of the liver, skin, fin, retinas, and the sensory epithelium cells of the inner ear of zebrafish embryos, apart from being involved in cell proliferation, migration, and survival [31,32]. A differential gene expression of mmp9, junba and haus3, genes involved in the development, was observed between $34{ }^{\circ} \mathrm{C}$ and $36^{\circ} \mathrm{C}$. Even that, the relative expression changes of these last-mentioned genes are really low (Figure $4 \mathrm{~A}$ ). This result supports selecting $36^{\circ} \mathrm{C}$ as a good temperature for xenograft assays when the incubation time is reduced. 
After embryo recovery at $28^{\circ} \mathrm{C}$ for $72 \mathrm{~h}$, gene expression reverted to normal (gene expression observed in embryos continuously incubated at $28^{\circ} \mathrm{C}$ ). Even this, some differences still persisted for socs $3 a$, haus3 and csf3b (Figure 4B). The expression of $\operatorname{socs} 3 a$ was downregulated after recovery in embryos incubated at $36^{\circ} \mathrm{C}$ when compared to embryos incubated at $34{ }^{\circ} \mathrm{C}$. The tissue regeneration during recovery at $28^{\circ} \mathrm{C}$ could be the reason behind this observation. On the other hand, $c s f 3 b$, involved in immune response (neutrophil chemotaxis), remains upregulated after recovery from $36^{\circ} \mathrm{C}$ compared to recovery from incubation at $34^{\circ} \mathrm{C}$. This could be suggesting that a persistent inflammation due to the stress induced by the high incubation temperature could be a long-term effect. All-in-all, most of the alterations observed in gene expression consequence of incubation for $48 \mathrm{~h}$ at temperatures higher than optimal up to $36{ }^{\circ} \mathrm{C}$, mostly revert to normal after a recovery period of $72 \mathrm{~h}$.

\section{Conclusions}

While there are differences in mortality and certain malformations are observed in zebrafish embryos incubated at $34^{\circ} \mathrm{C}$ and $36^{\circ} \mathrm{C}$ from $0 \mathrm{hpf}$ to $48 \mathrm{hpf}$, this is not the case when embryos are incubated at the same temperatures, but from $48 \mathrm{hpf}$ to $96 \mathrm{hpf}$. This implies that a 2 day incubation period from $48 \mathrm{hpf}$ to $96 \mathrm{hpf}$ at $36{ }^{\circ} \mathrm{C}$ could be used for xenograft assays in the yolk sack or other parts of embryos for more robust and accurate results in terms of tumor cell proliferation and/or invasion in response to drug testing in vivo.

The temperature effects over gene expression were mostly observed between the control condition at $28{ }^{\circ} \mathrm{C}$ with respect to $34{ }^{\circ} \mathrm{C} / 36^{\circ} \mathrm{C}$ after $48 \mathrm{~h}$ of incubation. After the $72 \mathrm{~h}$ recovery period, the temperature effects over gene expression is reverted for most genes, with the exception of socs $3 a$, haus $3, i l 1 b, c s f 3 a$ and $c s f 3 b$. Differences in gene expression for embryos incubated at $34^{\circ} \mathrm{C}$ and $36^{\circ} \mathrm{C}$ were observed for genes related to development (mmp9, junba and haus3), not interfering in the xenograft technique.

Supplementary Materials: The following are available online at https:/ / www.mdpi.com/2073-442 5/12/1/113/s1, Figure S1: Effect of temperature on development from $0 \mathrm{hpf}$ to $48 \mathrm{hpf}$ in zebrafish embryos. Figure S2: Effect of temperature on the viability of $48 \mathrm{hpf}$ zebrafish embryos. Figure S3: Representative images of each time point of the xenografted embryos with MCF7-GFP human cells. Table S1: qPCR primers sequence.

Author Contributions: Conceptualization, P.C.-S., J.A.R. and L.S.; funding acquisition, L.M.-R., R.L.-L. and L.S.; investigation, P.C.-S., C.C., P.F., A.P.-L.; methodology, P.C.-S., C.C., P.F., A.P.-L.; supervision, L.M.-R., R.L.-L., J.A.R. and L.S.; writing—original draft, P.C.-S. and J.A.R.; writingreview and editing, P.C.-S., J.A.R., L.M.-R., R.L.-L. and L.S. All authors have read and agreed to the published version of the manuscript.

Funding: This research is funded by 'Consolidación e estruturación de unidades de investigación competitivas do SUG. Grupos de referencia competitiva' (ED431C 2018/29) and 'Axuda á formación da etapa predoutoral' of Xunta de Galicia.

Institutional Review Board Statement: The study was conducted according to the guidelines of the Declaration of Helsinki, and approved by Ethics Committee of the University of Santiago de Compostela (15,010/2015/001).

Informed Consent Statement: Not applicable.

Data Availability Statement: The data presented in this study are available within the article and/or Supplementary Materials.

Acknowledgments: We thank V. Pérez Cedrón and M. Villar for maintaining the zebrafish facilities and supplying zebrafish eggs every day for our experiments.

Conflicts of Interest: The authors declare no conflict of interest. 


\section{References}

1. Haldi, M.; Ton, C.; Seng, W.L.; McGrath, P. Human melanoma cells transplanted into zebrafish proliferate, migrate, produce melanin, form masses and stimulate angiogenesis in zebrafish. Angiogenesis 2006, 9, 139-151. [CrossRef]

2. Tonon, F.; Zennaro, C.; Dapas, B.; Carraro, M.; Mariotti, M.; Grassi, G. Rapid and cost-effective xenograft hepatocellular carcinoma model in Zebrafish for drug testing. Int. J. Pharm. 2016, 515, 583-591. [CrossRef] [PubMed]

3. Ikonomopoulou, M.P.; Fernandez-Rojo, M.A.; Pineda, S.S.; Cabezas-Sainz, P.; Winnen, B.; Morales, R.A.V.; Brust, A.; Sánchez, L.; Alewood, P.F.; Ramm, G.A.; et al. Gomesin inhibits melanoma growth by manipulating key signaling cascades that control cell death and proliferation. Sci. Rep. 2018, 8, 1-14. [CrossRef] [PubMed]

4. Costa, B.; Ferreira, S.; Póvoa, V.; Cardoso, M.J.; Vieira, S.; Stroom, J.; Fidalgo, P.; Rio-Tinto, R.; Figueiredo, N.; Parés, O.; et al. Developments in zebrafish avatars as radiotherapy sensitivity reporters-Towards personalized medicine. EBioMedicine 2020, 51, 102578. [CrossRef] [PubMed]

5. Fior, R.; Póvoa, V.; Mendes, R.V.; Carvalho, T.; Gomes, A.; Figueiredo, N.; Ferreira, M.G. Single-cellfunctional and chemosensitive profiling of combinatorial colorectal therapy in zebrafish xenografts. Proc. Natl. Acad. Sci. USA 2017, 114, E8234-E8243. [CrossRef] [PubMed]

6. Fu, A.; Peh, Y.M.; Ngan, W.; Wei, N.; Luo, K.Q. Rapid identification of antimicrometastases drugs using integrated model systems with two dimensional monolayer, three dimensional spheroids, and zebrafish xenotransplantation tumors. Biotechnol. Bioeng. 2018, 115, 2828-2843. [CrossRef]

7. Cabezas-Sáinz, P.; Guerra-Varela, D.J.; Carreira, M.J.; Mariscal, J.; Roel, M.; Rubiolo, J.A.; Sciara, A.A.; Abal, M.; Botana, L.M.; Lopez, R.L.; et al. Improving zebrafish embryo xenotransplantation conditions by increasing incubation temperature and establishing a proliferation index with ZFtool. BMC Cancer 2018, 18, 1-12. [CrossRef]

8. Westerfield, M. The Zebrafish Book. A Guide for the Laboratory Use of Zebrafish (Danio Rerio), 4th ed.; University of Oregon Press: Eugene, OR, USA, 2000.

9. Dakappa, P.H.; Mahabala, C. Analysis of Long-Term Temperature Variations in the Human Body. Crit. Rev. Biomed. Eng. 2015, 43, 385-399. [CrossRef]

10. Long, Y.; Li, L.; Li, Q.; He, X.; Cui, Z. Transcriptomic Characterization of Temperature Stress Responses in Larval Zebrafish. PLoS ONE 2012, 7, e37209. [CrossRef]

11. Lee, L.M.; Seftor, E.A.; Bonde, G.; Cornell, R.A.; Hendrix, M.J. The fate of human malignant melanoma cells transplanted into zebrafish embryos: Assessment of migration and cell division in the absence of tumor formation. Dev. Dyn. 2005, 233, 1560-1570. [CrossRef]

12. Yang, X.-J.; Cui, W.; Gu, A.; Xu, C.; Yu, S.-C.; Li, T.-T.; Cui, Y.-H.; Zhang, X.; Bian, X.-W. A Novel Zebrafish Xenotransplantation Model for Study of Glioma Stem Cell Invasion. PLoS ONE 2013, 8, e61801. [CrossRef] [PubMed]

13. Zhang, B.; Shimada, Y.; Kuroyanagi, J.; Umemoto, N.; Nishimura, Y.; Tanaka, T. Quantitative Phenotyping-Based In Vivo Chemical Screening in a Zebrafish Model of Leukemia Stem Cell Xenotransplantation. PLoS ONE 2014, 9, e85439. [CrossRef] [PubMed]

14. Bansal, N.; Davis, S.; Tereshchenko, I.; Budak-Alpdogan, T.; Zhong, H.; Stein, M.N.; Kim, I.Y.; DiPaola, R.S.; Bertino, J.R.; Sabaawy, H.E. Enrichment of human prostate cancer cells with tumor initiating properties in mouse and zebrafish xenografts by differential adhesion. Prostate 2013, 74, 187-200. [CrossRef]

15. Konantz, M.; Balci, T.B.; Hartwig, U.F.; Dellaire, G.; André, M.C.; Berman, J.N.; Lengerke, C. Zebrafish xenografts as a tool for in vivo studies on human cancer. Ann. N. Y. Acad. Sci. 2012, 1266, 124-137. [CrossRef]

16. Ørnsrud, R.; Gil, L.; Waagbø, R. Teratogenicity of elevated egg incubation temperature and egg vitamin A status in Atlantic salmon, Salmo salar L. J. Fish Dis. 2004, 27, 213-223. [CrossRef]

17. Pype, C.; Verbueken, E.; Saad, M.A.; Casteleyn, C.R.; Van Ginneken, C.J.; Knapen, D.; Van Cruchten, S.J. Incubation at 32.5 degrees $\mathrm{C}$ and above causes malformations in the zebrafish embryo. Reprod. Toxicol. 2015, 56, 56-63. [CrossRef]

18. Laux, D.W.; Kelly, L.; Bravo, I.R.; Ramezani, T.; Feng, Y. Live imaging the earliest host innate immune response to preneoplastic cells using a zebrafish inducible KalTA4-ER(T2)/UAS system. Methods Cell Biol. 2017, 138, 137-150. [PubMed]

19. Meijer, A.H. Protection and pathology in TB: Learning from the zebrafish model. Semin. Immunopathol. 2016, 38, 261-273. [CrossRef]

20. van der Ent, W.; Burrello, C.; de Lange, M.J.; van der Velden, P.A.; Jochemsen, A.G.; Jager, M.J.; Snaar-Jagalska, B.E. Embryonic Zebrafish: Different Phenotypes after Injection of Human Uveal Melanoma Cells. Ocul. Oncol. Pathol. 2015, 1, 170-181. [CrossRef] [PubMed]

21. Kirchberger, S.; Sturtzel, C.; Pascoal, S.; Distel, M. Quo natas, Danio?-Recent Progress in Modeling Cancer in Zebrafish. Front. Oncol. 2017, 7, 186. [CrossRef]

22. Volkel, P.; Dupret, B.; Le Bourhis, X.; Angrand, P.O. The zebrafish model in oncology. Med. Sci. 2018, 34, $345-353$.

23. Idilli, A.I.; Precazzini, F.; Mione, M.; Anelli, V. Zebrafish in Translational Cancer Research: Insight into Leukemia, Melanoma, Glioma and Endocrine Tumor Biology. Genes 2017, 8, 236. [CrossRef] [PubMed]

24. Letrado, P.; De Miguel, I.; Lamberto, I.; Díez-Martínez, R.; Oyarzabal, J. Zebrafish: Speeding Up the Cancer Drug Discovery Process. Cancer Res. 2018, 78, 6048-6058. [CrossRef] [PubMed]

25. Nicoli, S.; Presta, M. The zebrafish/tumor xenograft angiogenesis assay. Nat. Protoc. 2007, 2, 2918-2923. [CrossRef] [PubMed]

26. Stoletov, K.; Kato, H.; Zardouzian, E.; Kelber, J.; Yang, J.; Shattil, S.; Klemke, R.L. Visualizing extravasation dynamics of metastatic tumor cells. J. Cell Sci. 2010, 123, 2332-2341. [CrossRef]

27. Eguiara, A.; Holgado, O.; Beloqui, I.; Abalde, L.; Sanchez, Y.; Callol, C.; Martin, A.G. Xenografts in zebrafish embryos as a rapid functional assay for breast cancer stem-like cell identification. Cell Cycle 2011, 10, 3751-3757. [CrossRef] 
28. He, S.; Lamers, G.E.; Beenakker, J.M.; Cui, C.; Ghotra, V.P.; Danen, E.H.; Meijer, A.H.; Spaink, H.P.; Snaar-Jagalska, B.E. Neutrophil-mediated experimental metastasis is enhanced by VEGFR inhibition in a zebrafish xenograft model. J. Pathol. 2012, 227, 431-445. [CrossRef]

29. Spaink, H.P.; Cui, C.; Wiweger, M.I.; Jansen, H.J.; Veneman, W.J.; Marín-Juez, R.; De Sonneville, J.; Ordas, A.; Torraca, V.; Van Der Ent, W.; et al. Robotic injection of zebrafish embryos for high-throughput screening in disease models. Methods 2013, 62, 246-254. [CrossRef]

30. Ren, D.L.; Wang, X.B.; Hu, B. Circadian gene period1b regulates proinflammatory cytokine expression through NF-kappaB signalling in zebrafish. Fish Shellfish Immunol. 2018, 80, 528-533. [CrossRef]

31. Khaliq, M.; Ko, S.; Liu, Y.; Wang, H.; Sun, Y.; Solnica-Krezel, L.; Shin, D. Stat3 Regulates Liver Progenitor Cell-Driven Liver Regeneration in Zebrafish. Gene Expr. 2018, 18, 157-170. [CrossRef]

32. Liang, J.; Wang, D.; Renaud, G.; Wolfsberg, T.G.; Wilson, A.F.; Burgess, S.M. The stat3/socs3a Pathway Is a Key Regulator of Hair Cell Regeneration in Zebrafish stat3/socs3a Pathway: Regulator of Hair Cell Regeneration. J. Neurosci. 2012, 32, 10662-10673. [CrossRef] [PubMed] 